\title{
Do Good Old Philosophical Values Work Today? Polish Students' Value Priorities in 2006 and 2017 - A Comparative Study
}

BACKGROUND. Values are concepts or beliefs about desirable end states or behaviors, that transcend specific situations, guide selection or evaluation of behavior and events, and are ordered by relative importance. Referring to Scheler's philosophical concept, the hierarchies of values among Polish students were compared between 2006 (Fanslau \& Brycz, 2006) and 2017.

PARTICIPANTS AND PROCEDURE. 603 (in total) adults participated in two studies. All of them were undergraduate students of various Universities from the Tri-City. They filled in the Scheler's Value Scale.

RESULTS. The results showed that the model hierarchy of values postulated by philosophers is not reflected in the minds of young (18-33 years old) Poles now and it was not reflected over a decade ago either. Moreover, significant differences between the levels of certain values were found.

CONCLUSIONS. It turned out that philosophical theories once accepted and adapted to psychology no longer have the same meaning as before. Value priorities change and they are ordered according to subjective validity.

Key words: values, hierarchy, young adults

\section{Background}

Personality, motivational and social psychology yield a large number of values definitions. However, there are five features that are common to most of these definitions: values are concepts or beliefs about desirable end states or behaviors, that

1 Uniwersytet Gdański; agnieszka.fanslau@ug.edu.pl.

2 Uniwersytet Gdański; psyhb@ug.edu.pl. 
transcend specific situations, guide selection or evaluation of behavior and events, and are ordered by relative importance (e.g., Rokeach 1973; Schwartz 1992). Values measurement consists of ordering them from the least to the most important or separately estimating their validity as "principles that guide my life". Values reflect preferences for what ideally ought to be. Both individuals and societies vary in the importance they place on different values (Fischer \& Schwartz 2011). They are conveyed to society members directly, but also through laws, norms, organizational practices and the media (Daniel et al. 2014). In addition, there is a longstanding interest in how personal values change across the life span as a result of life adaptations (e.g., Erikson 1980). Large number of studies take into account sex or age differences in value priorities (e.g., Schwartz \& Rubel 2005; Schwartz \& Rubel-Lifschitz 2009; Fung et al. 2016). In this article however, we take a closer look at the hierarchy of values among Polish students, living temporarily or permanently in Pomeranian voivodeship and test, whether there are any differences between young people's value priorities affirmed in 2006 and in 2017. We also check what place in the minds of young Poles occupy most abstract goals, namely: holy values (God, salvation, eternal life, nation, patriotism). The research adds to the existing literature in its focus on values of young people.

\section{Different approaches to values}

The author of the first concept of values, included in the psychology textbooks, was Gordon Allport. The Study of Values, as a way of measuring them, was first published in 1931. It was designed to measure six main values: theoretical (the dominant interest of the theoretical man is the discovery of truth), economic (the economic man is characteristically interested in what is useful), aesthetic (the aesthetic man sees his highest value in form and harmony), social (the highest value for this type is love of people), political (the political man is interested primarily in power), and religious (the highest value for the religious man may be called unity: he is mystical, and seeks to comprehend the cosmos as a whole, to relate himself to its embracing totality) (see Vernon, Allport 1931: 233-235). At the first version, the authors used the concept of values and interests interchangeably. They claimed that the SoV is intended to measure the relative importance of six universal interests as elements of personality. Rokeach's proposition was also to include values within the framework of personality theory. Unlike the Allport concept, it was an analysis in terms of cognitive psychology. (see Cieciuch 2013).

Milton Rokeach (1973) described two types of values, terminal and instrumental, corresponding to idealized ends and means. He defined a value system as an hierarchical arrangement of values along a continuum of importance and 
postulated two value systems, one terminal and one instrumental, each with a rank-order structure of its own. Terminal values refer to desirable end-states of existence - the goals that a person would like to achieve during their lifetime and may vary among different groups of people in different cultures (e.g. a world at peace, family security, freedom, equality, happiness, wisdom, pleasure). Instrumental values refer to preferable modes of behavior (e.g. ambitious, broadminded, clean, cheerful, logical, imaginative, polite, loving). These are preferable modes of behavior, or means of achieving the terminal values (Rokeach 1973).

According to Shalom Schwartz (1992) values form a circular motivational continuum in which adjacent values on the circle are compatible, have similar motivational meanings, and can be pursued simultaneously through the same behavior. In contrast, opposite values on the circle express conflicting motivations. He originally identified 10 motivationally distinct basic values that are recognized across societies: power (social status and prestige, control or dominance over people and resources), achievement (personal success through demonstrating competence according to social standards, hedonism (pleasure and sensuous gratification for oneself), stimulation (excitement, novelty, and challenge in life), self-direction (independent thought and action-choosing, creating, exploring, universalism (understanding, appreciation, tolerance, and protection for the welfare of all people and for nature), benevolence (preservation and enhancement of the welfare of people with whom one is in frequent personal contact), tradition (respect, commitment, and acceptance of the customs and ideas that traditional culture or religion provide the self), conformity (restraint of actions, inclinations, and impulses likely to upset or harm others and violate social expectations or norms), security (safety, harmony, and stability of society, of relationships, and of self). They can be put across the value circle, which form two bipolar dimensions - the first dimension contrast self - transcendence values (universalism and benevolence) with self - enhancement values (power and achievement). The second dimension contrasts openness to change values (stimulation and self-direction) with conservation values (tradition, conformity and security). Hedonism is located between the openness to change and self - enhancement dimensions. Recently Schwartz et al. (2012) proposed distinguishing between 19 facets by partitioning some of the 10 values into more narrowly defined values (security was divided into security-personal and security-societal; benevolence was dived into benevolence-dependability and benevolence-caring; universalism was divided into universalism-tolerance, universalism-concern and universalism-nature; conformity was divided into conformity-rules and conformity-interpersonal; power was divided into power-resources and power-dominance and self-direction was divided into self-direction-action and self-direction-thought). Moreover, they introduced two new, narrowly defined values between some earlier values. Face 
was defined as "security and power through maintaining one's public image and avoiding humiliation" and was located between security and power, and humility was defined as "recognizing one's insignificance in the larger scheme of things" and was placed between conformity and benevolence (Schwartz et al. 2012).

Max Scheler, a German philosopher, known for his work in phenomenology, ethics and philosophical anthropology postulated that values exist objectively and they are just as independent from the subject as material beings or logical and mathematical laws. Moreover, values are ideal, in contrast to material entities or mental beings, which are real. That is why they can only be grasped intuitively (see Tatarkiewicz 1990). There is, according to Scheler, an objective ranking of values, a ranking of the "lower" to the "higher," or better expressed, a ranking of the more superficial to the deeper. He claimed that the universal hierarchy of values embraces all aspects of human activity (Kuderowicz 1965). The ranking of value types from lowest to highest is as follows: pleasure, utility, vitality, spirituality, and holiness (Scheler 1975). Spiritual values divide into three groups: esthetical values (beauty), truth and moral values (see Scheler 1975; Tischner 1982; Brzozowski 1995). Scheler did not establish the order of spiritual values. According to Brzozowski (1995), esthetical values should be the lowest, because of their similarity to pleasure values (e.g. beauty usually ensure sensual pleasure). Truth values should be therefore subordinate to moral values. The values ranking proposed by Tischner (1982) is compatible to Scheler's hierarchy - the lowest are hedonistic values, because they provide only temporary pleasures which can pose a potential threat to life and health. Life-giving (vital) values should be therefore more important. Spiritual values should, in turn, give meaning to life, a sense of happiness, and be something deeper and permanent than life-giving values. Tischner (1982) also claims that even spiritual values have to have their own substantiation - when a man sacrifices himself for the truth, justice or freedom, he has to refer to the holy values: God (if he is a believer), nation, history or homeland. Brzozowski (1995) also argues that if the universal hierarchy of values actually exists, then a person's emotional, cognitive and social development should lead to its discovery.

In our comparative study the question we sought an answer for was whether Polish students differ in relation to their value priorities between 2006 and 2017.

\section{The present research}

In the study carried out in 2017 we repeated the value survey among students from 2006 (Fanslau \& Brycz 2006). The aim of it was to compare student's value priorities. To assess them we used the Scheler's Value Scale (SVS). The SVS (D-50 version), constructed by Brzozowski (1995) consists of 50 values, put into six basic value categories: hedonistic, life-giving, esthetic, truth, moral, and holy. 
The basic 6 categories consist of the following items:

1. hedonistic -8 items: prosperous life, erotic love, possession, pleasure, joy of life, convenience, rest, life full of impressions (adventurous life);

2. life-giving - 6 items: resistance to fatigue, physical strength, fitness, body elasticity, resistance to cold (ability to bear the cold), resistance to hunger (ability to cope with hunger);

3. esthetic - 7 items: elegance, taste, harmony, order of things, proportionality of shapes, regularity of features, order;

4. truth - 8 items: intelligence, consistency, wisdom, objectivity, open mind, understanding, broad (mental) horizons, knowledge;

5. moral - 11 items: kindness, honor (reputation), love, peace, helping others, truthfulness, reliability, sincerity, honesty, kindness, benevolence;

6. holy - 10 items: God, country, nation, independence, homeland, state, patriotism, faith, salvation, eternal life.

Four factor subscales consist of the following items:

1. fitness and physical strength -3 items: physical strength, fitness, body elasticity;

2. resistance -3 items: resistance to fatigue, resistance to cold (ability to bear the cold), resistance to hunger (ability to cope with hunger);

3. lay sanctity (patriotic) - 6 items: country, nation, independence, homeland, state, patriotism;

4. religious sanctity - 4 items: God, faith, salvation, eternal life.

The items are ordered alphabetically on the test sheet. To complete the scale, all values have to be evaluated on the 101-point scale (from 0 to 100), where "0" means that the value is neutral, and " 100 " means that the value is the most important.

We decided to use this scale in our research for three reasons. First, it seems to fit in with the assessment of values in Polish society, where $88 \%$ of the total population declares affiliation to the Roman Catholic Church. Second, we wanted to see whether the emphasis on the conservative and religious values put on by the right - wing Law and Justice party which assumed full power in Poland in 2015 is shared by Polish students. The third reason was dictated by the ease of comparing two studies, where the same tools of research are used.

\section{Method}

\section{Questions}

1. Is there any difference in the importance attached to value priorities by students between 2006 and 2017?

2. What is the hierarchy of values among Polish students? 


\section{Participants}

603 (in total) adults participated in two studies. All of them were undergraduate students of Gdańsk University, Gdańsk University of Technology, WSB University of Gdańsk, Gdynia Maritime University and Polish Naval Academy in Gdynia. In 2006308 students (aged between 18 and $30, M=22.70, S D=2.01$ ) took part in the study. In 2017295 students (aged between 18 and 33, $M=21.77, S D=1.91$ ) participated in the follow up study. Participants were eligible if they were 18 or older, undergraduate and Polish. No reward was given for the participation in the study.

\section{Procedure}

Students worked in classrooms (groups of 15-20 people). All of them were assured about the scientific goal of our study and their anonymity. Afterwards, they filled in the Scheler's Value Scale (SVS). The reliability of the SVS was satisfactory: in 2006 Cronbach's $\alpha=0.92$, in 2017: Cronbach's $\alpha=0.87$. Nobody was unsure about their gender. All participants understood the task and filled in the SVS. There was no reason to exclude any of the subjects.

\section{Variables}

Independent variable: Time of values' measurement: 2006 vs. 2017

Dependent variable: Raw average score for all values: hedonistic, life-giving, esthetic, truth, moral, holy

\section{Results}

In order to answer the questions we conducted the analysis of variance (one-way ANOVA): 2 Time (2006 vs. 2017) 1 Group separately for each dependent measure.

In the study we wondered whether the importance of values among Polish students might change after 11 years. We found significant differences for the following values (main effects):

- hedonistic: $F(1,601)=26.59, p<.001, \eta^{2}=0.04$, with the higher importance of the value in 2006: $M=74.24, S D=0.82$ than in 2017: $M=68.01, S D=0.85$;

- life-giving: $F(1,601)=9.87, p=.002, \eta^{2}=0.02$, with the higher importance of the value in 2006: $M=59.32, S D=1.10$ than in 2017: $M=54.28, S D=1.13$;

- esthetic: $F(1,601)=3.71, p=.05, \eta^{2}=0.01$, again with the higher importance in 2006: $M=54, S D=1.04$ than in 2017: $M=51.07, S D=1.07$;

- holy: $F(1,601)=22.21, p<.001, \eta^{2}=0.04$ with higher importance in 2006: $M=66.34, S D=1.26$ than in $2017: M=57.61, S D=1.29$. 
However, no change was observed for two values. These values are:

- $\underline{\text { truth: }} F(1,601)=2.93, p=.10 ; 2006: M=77.38, S D=0.8$ vs. $2017 M=75.71$, $S D=0.78$, and

- $\underline{\text { moral: }} F(1,601)=0.10, p=.75 ; 2006: M=77.72, S D=0.71$ vs. $2017 M=77.53$, $S D=0.72$.

Figure 1 presents the change that occurred in values importance for Polish students between 2006 and 2017.

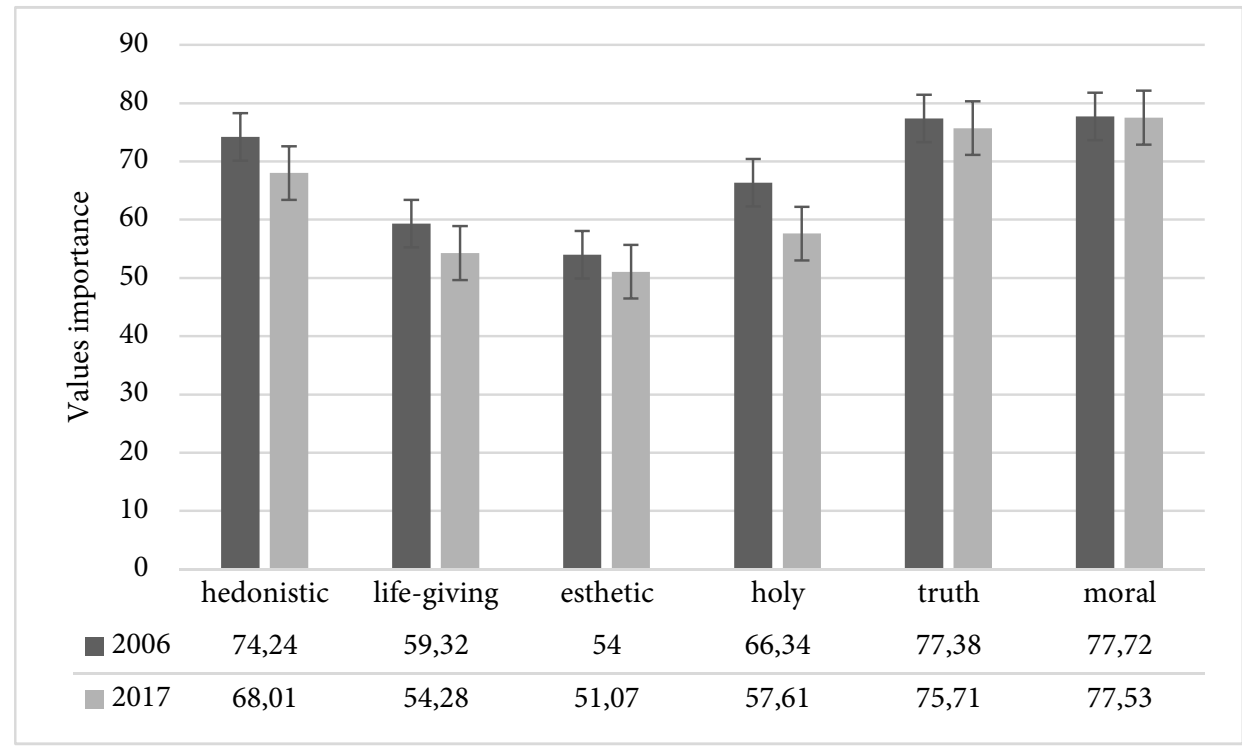

Figure 1. The Difference in Values Importance for Polish Students Between 2006 and 2017

Source: own elaboration.

Despite the fact that the significant change between 2006 and 2017 in the importance attached to most of the values was observed, the hierarchy of them remained unaffected (Table 1).

As shown in Table 1, students rated esthetic values as the lowest and moral values - as the highest. Interestingly, hedonistic values are consistently found in the higher values, while religious values are put within the lower values. A comparison of the exemplary hierarchy postulated by Max Scheler and the students' hierarchy can be found in Table 2 . 
Table 1. The Average Importance of Values in Ascending Order

\begin{tabular}{lcccccc}
\hline \multirow{2}{*}{ Values } & \multicolumn{2}{c}{2006} & \multicolumn{2}{c}{2017} & \multirow{2}{*}{$F(1.595)$} & \multirow{2}{*}{$p$} \\
\cline { 2 - 5 } & $M$ & $S D$ & $M$ & $S D$ & & .05 \\
\hline Esthetic & 54.00 & 1.04 & 51.07 & 1.07 & 3.73 & .001 \\
\hline Life-giving & 59.32 & 1.10 & 54.28 & 1.13 & 10.18 & $<.001$ \\
\hline Religious sanctity & 66.14 & 1.81 & 56.64 & 1.86 & 13.40 & $<.001$ \\
\hline Lay sanctity & 66.50 & 1.38 & 58.27 & 1.41 & 17.39 & $<.001$ \\
\hline Hedonistic & 74.24 & 0.82 & 68.01 & 0.85 & 27.87 & .14 \\
\hline Truth & 77.38 & 0.80 & 75.71 & 0.78 & 2.24 & .85 \\
\hline Moral & 77.72 & 0.85 & 77.53 & 0.72 & 0.04 & \\
\hline
\end{tabular}

Source: own elaboration.

Table 2. Comparison of the Exemplary Hierarchy and the Students' Hierarchy

\begin{tabular}{lccccccc}
\hline \multicolumn{3}{c}{ Lower } & \multicolumn{4}{c}{ Higher } \\
\hline $\begin{array}{l}\text { Scheler's } \\
\text { exemplary } \\
\text { hierarchy }\end{array}$ & Hedonistic & $\begin{array}{c}\text { Life- } \\
\text { giving }\end{array}$ & Esthetic & Truth & Moral & $\begin{array}{c}\text { Lay } \\
\text { sanctity }\end{array}$ & $\begin{array}{c}\text { Religious } \\
\text { sanctity }\end{array}$ \\
\hline $\begin{array}{l}\text { Students' } \\
\text { hierarchy }\end{array}$ & Esthetic & $\begin{array}{c}\text { Life- } \\
\text { giving }\end{array}$ & $\begin{array}{c}\text { Religious } \\
\text { sanctity }\end{array}$ & $\begin{array}{c}\text { Lay } \\
\text { sanctity }\end{array}$ & Hedonistic & Truth & Moral \\
\hline
\end{tabular}

Source: own elaboration.

\section{Discussion}

In the study reported in this article the authors compared value priorities among Polish students between 2006 (Fanslau \& Brycz 2006) and 2017. The results show that the weight attached to most values, that is hedonistic, life-giving, esthetic and holy (measured with Scheler's Value Scale) has decreased over time. This trend, however, doesn't apply to truth and moral values, which importance remains unchanged, and place those two at the highest level. Despite the fact that the significant change between 2006 and 2017 in the importance attached to most of the values was observed, the hierarchy itself remained unaffected. So if students are asked to rank values from the least to the most important, they put them in the following order: esthetic, life-giving, holy, hedonistic, truth and moral. This hierarchy, which seems to be typical for Polish students living in Pomeranian voivodeship, is far from the exemplary (model) hierarchy postulated by Scheler. Students put hedonistic values (prosperous life, erotic love, possession, pleasure, joy of life, convenience, rest, life full of impressions) much higher than holy values (God, country, nation, independence, homeland, state, patriotism, faith, salvation, eternal life). Why? Research proves (e.g. Fung et al. 2016) that subjective well - being is enhanced when individuals endorse values that are appropriate for their age and 
fulfill their needs. Thus appreciating hedonistic values so much by young people is developmental (as well as beneficial) - they set and pursue age-related goals, one of which is to maximize pleasure and minimize pain. Additionally, the socioemotional selectivity theory (Carstensen et al. 1999) posits that one of the ways in which individuals select goals is in accordance with their perceptions of future time - limited or open ended. For young people future time perspective is not limited, so a hedonistic approach to life is a goal which optimize the future. Moreover, it looks like that together with truth (intelligence, understanding, knowledge) and moral (kindness, honesty, benevolence), hedonistic values represent a genuine way to happiness for young Poles. This is consistent with the notion of positive psychology, where pleasure, positive relationships, and accomplishments along with engagement and meaning, constitute the authentic happiness pathways (Seligman 2011). In contrast to Scheler's concept, hedonistic values are no longer connected with something bad or threatening.

In turn, depreciation of holy values by students (which consist of religious as well as patriotic values) is in contrast to the slow but steady increase in religious involvement of Poles in general. This involvement is also related to the rise of conservative and xenophobic attitudes (Social Diagnosis 2015: 367-368). However, it should be remembered that $41,9 \%$ of young people up to 34 years of age do not participate in religious practices at all, and in cities with over 500000 inhabitants this percentage rises to 54 (Social Diagnosis 2015: 284). Additionally, according to the Social Diagnosis (2015), only $10 \%$ of people living in the Pomeranian voivodeship (northern Poland) indicate God as one of the three cardinal values. Moreover, hedonistic approach to life generally excludes concentration on religion. Cherishing truth values may also limit trust in religion which calls for faith, not knowledge (Brzozowski 2007: 268).

Polish society in terms of interest and involvement in politics fall below the European average. Only $0.3 \%$ of people aged 16 or over are active in favor of a political party, and only $10 \%$ are active in favor of any organization (Social Diagnosis 2015). In the whole population, the participation in parliamentary, local or presidential elections does not exceed the 50\% threshold. Resent research proves that, in general, if the elections had taken place in 2017 , the elderly would have rather participate in the vote than younger respondents, as well as people with specific political views (rather the right-wing) and participating in religious practices (CBOS 2017: 9).

Seeking for an explanation for the value hierarchy professed by young people, it is also worth to compare it to the circular value model in Schwartz's theory. The attempt of integrating two approaches to values, that is the Schwartz's value theory and Scheler's value concept, was made by Cieciuch (2011). Using the multidimensional scaling method (MDS) he established that Schelerian values are 
connected with corresponding values on the Schwartz's value circle. Life-giving (vital), hedonistic and esthetic values were located in the same area of the circle as hedonistic, achievement and power (the self-enhancement higher order values), with life-giving values closer to the conservation higher order values and esthetic values closer to openness to change. Moreover, Schelerian values of truth were situated in the same area of the circle as self-direction and stimulation values (the openness to change higher order values), and moral values fit into the sphere of benevolence and universalism values, creating with them the higher order values of self-transcendence. Finally, holy values (both religious and patriotic) were located in the same area as tradition, conformity and security, which belong to the conservation higher order values (Cieciuch 2011: 210). Having in mind that, according to Schwartz's theory, only adjacent values on the circle are compatible, while opposite values express conflicting motivations, the hierarchy of values embraced by young people is not at all surprising. They appreciate values from the spheres of openness to change (like: the open mind, understanding, knowledge, pleasure, joy of life - if the expressed hedonism is closer to the stimulation values) and self - transcendence (like: honesty, sincerity, kindness, benevolence) much more than values from the self - enhancement (like: elegance, taste, proportionality of shapes, physical strength, fitness) and conservation areas (like: patriotism, faith, salvation, eternal life).

The groups of students we focused on repeatedly admit that for them the real "sanctities" are love, truthfulness, reliability, sincerity, honesty, kindness, and benevolence. At the same time, it turns out that philosophical theories once accepted and adapted to psychology no longer have the same meaning as before hedonism condemned by some philosophers is crucial for subjective well-being enhancement (which is consistent with the trend of positive psychology). Holy values, in turn, as philosophers perceived them, may be now associated with radicalism, political conservatism and religious prejudices, and therefore rejected by students.

\section{Limitations of present research}

The conclusions of the study presented here have limitations for at least two reasons. Firstly, the Schelers' Value Scale (SVS) is adapted only to Polish conditions, so it is not possible to use it for cross cultural research. Secondly, as the group of students was not a representative, national sample, conclusions on the hierarchy of values of young people cannot be generalized to the whole country. 
Bibliography

Brzozowski P., 1995, Skala Wartości Schelerowskich. Podręcznik [Scheler's Value Scale. Course book], Warszawa: Pracownia Testów Psychologicznych Polskiego Towarzystwa Psychologicznego.

Brzozowski P., 2007, Wzorcowa hierarchia wartości. Polska, europejska czy uniwersalna? [A model value hierarchy - Polish, European or universal?], Lublin: Wydawnictwo Uniwersytetu Marii Curie-Skłodowskiej.

Carstensen L.L., Isaakowitz D.M., Charles S.T., 1999, Taking time seriously: A theory of socioemotional selectivity, American Psychologist, vol. 54, no. 3, pp. 165-181, http:// web.a.ebscohost.com (access: 12.01.2018).

CBOS [Public Opinion Research Center], 2017, Chęć udziału w wyborach i zainteresowanie polityka. Komunikat $z$ badan nr 101/2017 [Willingness to take part in the elections and interest in politics. Research report No 101/2017], www.cbos.pl/SPISKOM. POL/2017/K_101_17.PDF (access: 12.01.2018).

Cieciuch J., 2011, Integration of Schwartz's values theory and Scheler's concept of values in research on the development of the structure of values during adolescence, Polish Psychological Bulletin, vol. 42(4), pp. 205-214, DOI: 10.2478/v10059-011-0027-5.

Cieciuch J., 2013, Kształtowanie się systemu wartości od dzieciństwa do wczesnej dorosłości [The development of the value system from childhood to early adulthood], Warszawa: Liberi Libri.

Daniel E., Benish-Weisman M., Boehnke K., Knafo A., 2014, Personal and culture-dependent values as part of minority adolescent identity [in:] R.K. Silbereisen, P.F. Titzmann, Y. Shavit (eds.), The Challenges of Diaspora Migration: Interdisciplinary Perspectives on Israel and Germany, Farnham: Ashgate.

Erikson E., 1980, Identity and the life cycle, New York: Norton.

Fanslau A., Brycz H., 2006, Pokusy i ich wpływ na natężenie wyznawanych wartości wśród młodych kobiet i mężczyzn [Temptations and their influence on values of young women and men] [in:] A. Chybicka, M. Kaźmierczak (eds.), Kobieta $w$ kulturze, kultura w kobiecie [A woman within the culture, the culture within a woman], Kraków: Impuls.

Fischer R., Schwartz S., 2011, Whence differences in value priorities? Individual, cultural, or artifactual sources, Journal of Cross-Cultural Psychology, vol. 42, pp. 1127-1144, DOI: 10.1177/0022022110381429.

Fung H.H., Ho Y.W., Zhang R., Zhang X., Noels K.A., Tam K.P., 2016, Age differences in personal values: Universal or cultural specific?, Psychology and Aging, vol. 31, no. 3, pp. 274-286, http://dx.doi.org/10.1037/pag0000082 (access: 12.01.2018).

Kuderowicz Z., 1965, Scheler - personalizm etyczny [in:] Filozofia i socjologia XX wieku, cz. 2, Myśli i Ludzie [Scheler - ethical personalism in: Philosophy and sociology of XX century, p. 2, Thoughts and People], Warszawa: Wiedza Powszechna.

Rokeach M., 1973, The nature of human values, New York: Free Press.

Scheler M., 1975, Aprioryczne powiązania o charakterze starszeństwa między modalnościami wartości [An a priori hierarchy of value modalities], Warszawa: Wiedza Powszechna.

Schwartz S.H., 1992, Universals in the content and structure of values: Theoretical advances and empirical tests in 20 countries [in:] M.P. Zanna (ed.), Advances in experimental social psychology, vol. 25, pp. 1-65, New York: Academic Press. 
Schwartz S.H., Rubel T., 2005, Sex differences in value priorities: Cross-cultural and multimethod studies, Journal of Personality and Social Psychology, vol. 89, pp. 1010-1028, DOI: 10.1037/0022-3514.89.6.1010.

Schwartz S.H., Rubel-Lifschitz T., 2009, Cross - national variation in the size of sex differences in values: Effects of gender equality, Journal of Personality and Social Psychology, vol. 97, no. 1, pp. 171-185. DOI: 10.1037/a0015546.

Schwartz S.H., Cieciuch J., Vecchione M., Davidom E., Fischer R., Beierlein C., Ramos A., Verkasalo M., Lönnqvist J.E., Demirutku K., Dirilen-Gumus O., Konty M., 2012, Refining the theory of basic individual values, Journal of Personality and Social Psychology, vol. 103, no. 4, pp. 663-688, DOI: 10.1037/a0029393.

Seligman M.E.P., 2011, Flourish: A visionary new understanding of happiness and wellbeing, New York: Free Press.

Social Diagnosis, reports, 2015, Objective and subjective quality of life in Poland, J. Czapinski, T. Panek (eds.), http://www.diagnoza.com/pliki/raporty/Diagnoza_raport_2015.pdf (access: 12.01.2018).

Tatarkiewicz W., 1990, Historia filozofii, t. 3, Filozofia XIX wieku i współczesna [History of philosophy. Vol. 3, Philosophy of XIX century and contemporary philosophy], Warszawa: Wydawnictwo Naukowe PWN.

Tischner J., 1982, Myślenie według wartości [Thinking in values], Kraków: Znak.

Vernon P.E., Allport G.W., 1931, A test for personal values, The Journal of Abnormal and Social Psychology, vol. 26, no. 3, pp. 231-248, http://web.b.ebscohost.com (access: 12.01.2018). 